\title{
A seasonal study on phytoplankton diversity and dynamics of Lake Chamo, Ethiopia
}

\author{
Addisu Fekadu ${ }^{1,2, *}$ and Solomon Chanie ${ }^{2}$ \\ ${ }^{1}$ Arba Minch University, Biodiversity Research Center, P.O. Box 21, Arba Minch, Ethiopia \\ 2 Arba Minch University, Department of Biology, P.O. Box 21, Arba Minch, Ethiopia
}

Received 17 July 2016 / Accepted 15 September 2017

Handling editor: Véronique Martin-Jezequel

\begin{abstract}
Phytoplankton succession in open lakes depends on the availability of nutrients, temperature, light intensity and transparency. Phytoplankton communities usually undergo a fairly predictable annual cycle, but some species may grow exponentially forming the blooms. Accordingly, the seasonal diversity and dynamics of phytoplankton and their correlation with environmental factors were investigated in Lake Chamo, from December, 2013 to November, 2014. Samples were taken from four different sites of the lake; each of these sampling sites had their own unique characteristics. Seasonal plankton samples were collected using nylobolt plankton net (No. 25). pH, water temperature, specific conductivity, saturation, total dissolved solids, salinity and dissolved oxygen were measured in the field. The results showed that there is significant difference in the mean value of $\mathrm{pH}$ across the different seasons at the first sampling site, season II having significantly higher value than season I and IV. Water temperature also significantly varied among sampling sites and seasons, site 3 in spring 2014 having significantly higher value $\left(30.4 \pm 0.21^{\circ} \mathrm{C}\right)$ than site 2 during summer $2014\left(26.0 \pm 0.12^{\circ} \mathrm{C}\right)$. Cyanophyta, Chlorophyta and Bacillariophyta accounted $96 \%$ of the total phytoplankton abundance during the study period. Pediastrum, Scendesmus and Closterium species were the predominant Chlorophyta, during the rainy seasons. The average Cyanophyta count was positively and non-significantly correlated with water temperature and turbidity of the lake. Overall, the four seasons exhibit different phytoplankton species composition across different sites. The diversity was high during winter season in all sampling sites.
\end{abstract}

Keywords: Phytoplankton diversity / physicochemical parameters / species composition / Lake Chamo

\section{Introduction}

In aquatic ecosystems phytoplankton are the principal primary producers form the first trophic level of the aquatic food chain (Nasser and Sureshkumar, 2014). Hence they play an important role in the food webs as they provide food for zooplankton and other aquatic fauna (Jagadeeshappa and Kumara, 2013). Their presence is also essential to support a healthy aquatic ecosystem, and is frequently used as ecological indicator for the ecological health and the stress effects of chemical contaminants in aquatic ecosystems (Xu et al., 1999).

Phytoplankton diversity and dynamics in open lakes is largely dependent on abiotic factors such as nutrient availability, water temperature, light conditions and transparency, along with biotic interactions such as predation and competition (Siddaraju and Deviprasad, 2012; Jiang et al.,

*Corresponding author: addisufkd@yahoo.com
2014). Light limitation due to high turbidity is another factor that frequently controls phytoplankton growth over both annual and seasonal cycles (Ariyadej et al., 2004). Moreover, when single groups of organisms like algae compete for nutrients within a uniform environment, the diversity may be lower due to competitive exclusion. However, the biotic interactions between diverse freshwater plankton communities and how this influences overall community composition are highly complex (Siddaraju and Deviprasad, 2012).

Phytoplankton typically also undergo a fairly predictable annual and seasonal cycles (Jiang et al., 2014). The spatial and temporal variation highly influenced by the prevailing physicochemical parameters and these determine their abundance, occurrence and seasonal variations (Rothhaupt, 2000). Plankton respond quickly to environmental changes because of their short life cycle, hence, their species composition and dynamics are more likely to indicate the quality of the water which they are found. The relative abundance of chlorophyll is indicative of productive water 
(Washington, 1984; Jenkerson and Hickman, 2007). Ecologists have designed a range of indices and models for the measurement of phytoplankton diversity (Warwick, 1992). These diversity indices are applied in water pollution research to evaluate the effects of pollution on species composition (Archibald, 1972; Shashi et al., 2008). The qualitative and quantitative studies of phytoplankton have also been utilized to assess the quality of water (Shashi et al., 2008).

The importance of phytoplankton to trophic systems and overall ecosystem function means that understanding how communities respond to environmental parameters is important. Tropical lakes, particularly those in Africa, are known for their high primary productivity of phytoplankton (Sorokin et al., 2014) and thus present a useful system to study this issue. For example, recent studies on phytoplankton diversity in tropical African lakes, particularly in the soda lakes of East Africa, have come up with reports of exceptionally high diversity and photosynthetic activity (Lemma and Desta, 2016). Similarly, a high diversity of aquatic fauna has also been reported in Lake Chamo (Hailemicael and Raju, 2010; Willén et al., 2011). However, there are no clear reports which show phytoplankton diversity and abundance across different seasons in Lake Chamo. Therefore, the primary objective of this research was to assess phytoplankton diversity, abundance and dynamics with physicochemical parameters of Lake Chamo across different seasons.

\section{Materials and methods}

\subsection{Study area}

The study took place at Lake Chamo, a tectonic lake and the southernmost lake of the Ethiopian Rift Valley $\left(5^{\circ} 45^{\prime} \mathrm{N}\right.$ latitude and $37^{\circ} 30^{\prime} \mathrm{E}$ longitude), which covers an area of 45,000 ha, at an elevation of $1,233 \mathrm{~m}$. It has a maximum known depth of $12.7 \mathrm{~m}$. It is fed by the perennial Kulfo river, Kulfo that enters Lake Chamo from the north and by a number of small but non-perennial rivers including the Rivers Sile and Sego. The lake is characterized by a gently sloping shoreline covered by extensive emergent and submergent vegetation.

\subsection{Sample collection sites}

Samples were taken from four different sites of the lake, each of which had its own unique characteristics. Site 1 is situated close to the mouth of Kulfo river $\left(\mathrm{N}^{\circ} 5.55^{\prime} 05.07^{\prime \prime}\right.$, $\left.\mathrm{E}^{\circ} 37.33^{\prime} 34.8^{\prime \prime}\right)$. Site 2 is considered as the center of the lake $\left(\mathrm{N}^{\circ} 5.53^{\prime} 32.1^{\prime \prime}, \mathrm{E}^{\circ} 37.34^{\prime} 33.5^{\prime \prime}\right)$. Site 3 is near the mouth of Sile river $\left(\mathrm{N}^{\circ} 5.53^{\prime} 45.1^{\prime \prime}, \mathrm{E}^{\circ} 37.31^{\prime} 58.3^{\prime \prime}\right)$. Site 4 is located close to the main gate and is characterized by high disturbance $\left(\mathrm{N}^{\circ} 5.55^{\prime} 58.1^{\prime \prime}, \mathrm{E}^{\circ} 37.32^{\prime} 04.9^{\prime \prime}\right)$ (Fig. 1).

\subsection{Phytoplankton sampling}

Sampling took place between December 2013 and November 2014. Winter 2013/14 was considered as season I, spring 2014 season II, summer 2014 season III, and autumn 2014 season IV. Seasonal plankton, with two sampling times for each season, were collected from 4 sites of Lake Chamo using a nylobolt plankton net (No. $25 \mu \mathrm{m}$ ). To do so, two sampling techniques

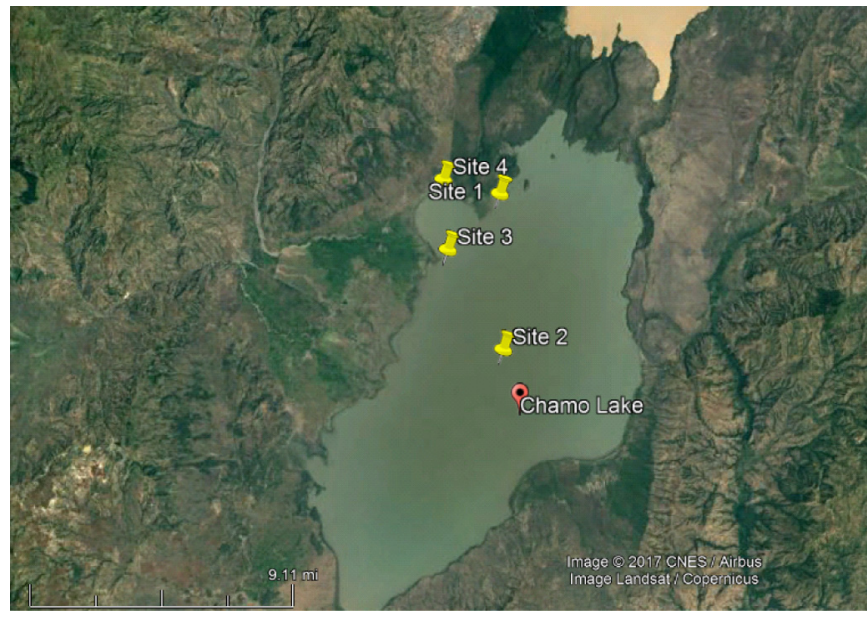

Source: Google Earth, 2017

Fig. 1. Study area and sampling sites.

were employed. Firstly, to assess species diversity, phytoplankton were pulled up vertically to the surface. The sample from the net was then placed into a $100 \mathrm{~mL}$ bottle. Typically, this process required 2-3 samples to fill the bottle. Secondly, for determining the abundance, phytoplankton were collected using a water sampler (Jagadeeshappa and Kumara, 2013; Jiang et al., 2014). Since the total depth of Lake Chamo is less than $15 \mathrm{~m}$, equal volumes were taken from the surface, mid-depth and bottom regions of the lake (Jagadeeshappa and Kumara, 2013; Jiang et al., 2014). Aliquots from each depth were combined and $1 \mathrm{~L}$ of the composite sample was poured into dark plastic bottles and preserved with $2 \mathrm{~mL}$ of Lugol's solution per $100 \mathrm{~mL}$ of the water for later analysis. For counting, samples were sedimented in glass columns (Welch, 1948) and studied with an inverted microscope. Calculation of phytoplankton abundance (per liter) was based on the cell counts from sub samples. All types of phytoplankton samples were taken to Limnology Laboratory of Addis Ababa University for identification and abundance estimation. Moreover, several special publications from tropical environments and Monographs of Desikachary (1959), (Philipose, 1962; Prescott, 1982), and (Sarode and Kamath, 1984) were consulted.

\subsection{Physicochemical parameters measurements}

The physicochemical parameters $\mathrm{pH}$, water temperature, specific conductivity, saturation, total dissolved solids, salinity and dissolved oxygen were measured in the field using HQ40D digital multi probes meter (HACH, USA). Chlorophyll-a concentrations and turbidity were measured in the field with a hand-held fluorometer, Aqua Fluor ${ }^{\mathrm{TM}}$ (Turner Designs, San Jose, California), and water transparency was also measured using a white and black Secchi disc of $20 \mathrm{~cm}$ diameter. All the parameters were measured in three replicates. Water samples were also collected from the surface and stored in a cool box at $4{ }^{\circ} \mathrm{C}$. These samples were later analyzed for total alkalinity (TA), total hardness (TH), total dissolved solid (TDS), chlorides, calcium, magnesium, sulphate, nitrate and total nitrogen (TN) at Arba Minch University Water Quality Laboratory using standard methods (APHA, 2005). 

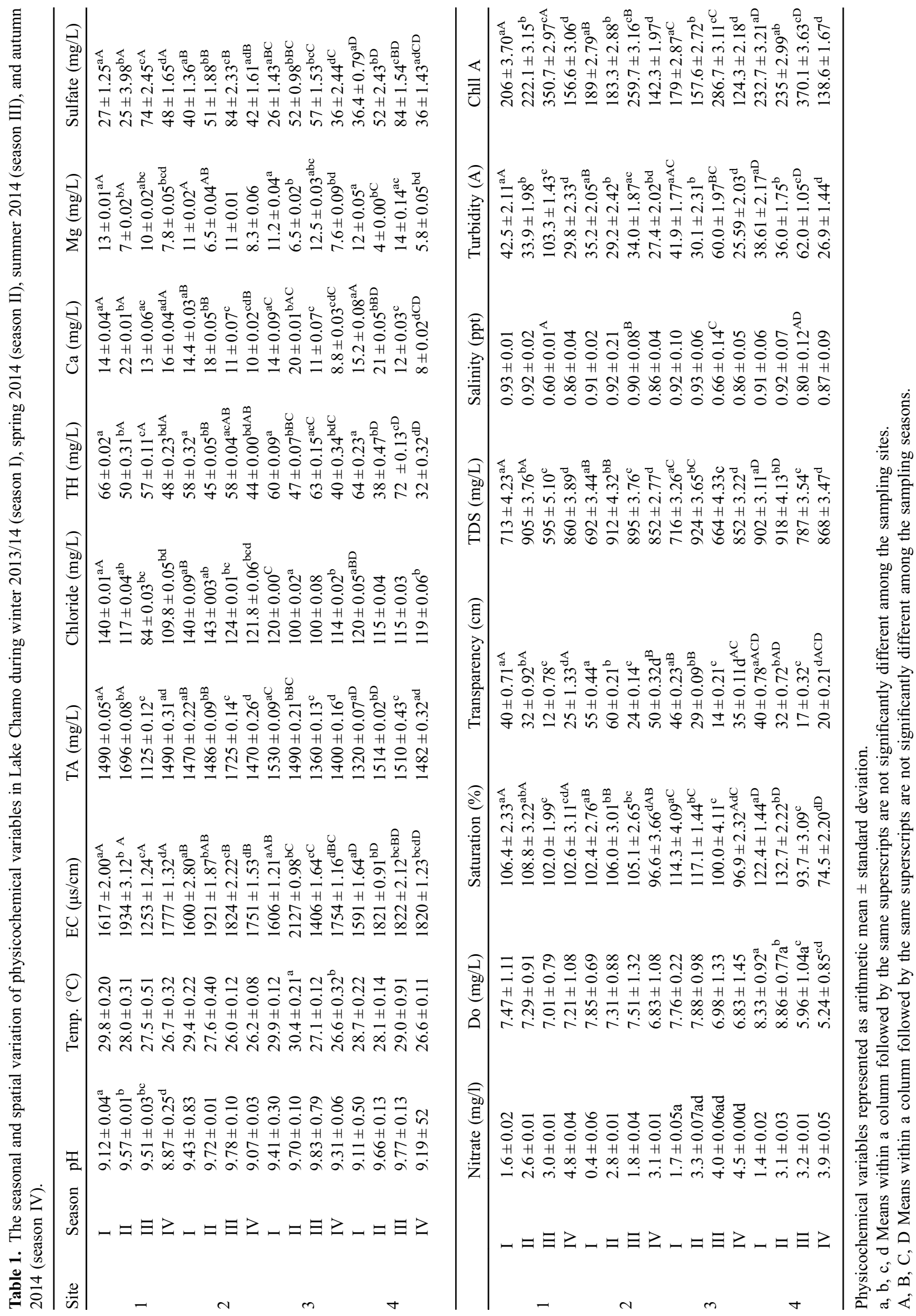


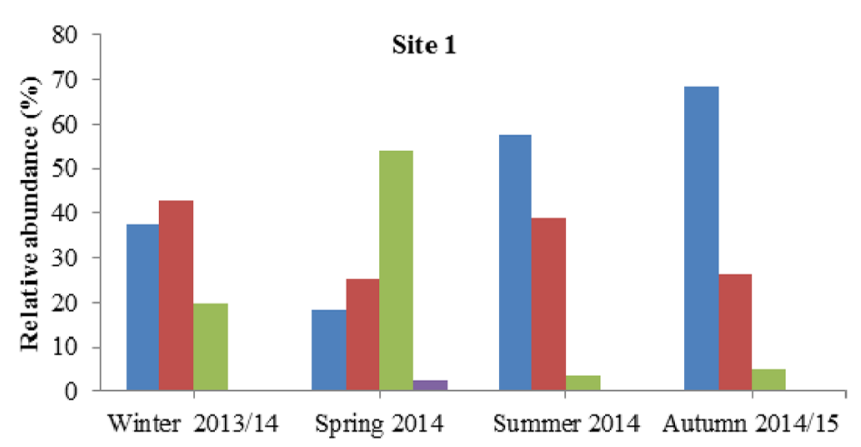

ఐCyanophyceae $₫$ Chlorophyceae $₫$ Bacillariophyceae $\square$ Euglenophyceae

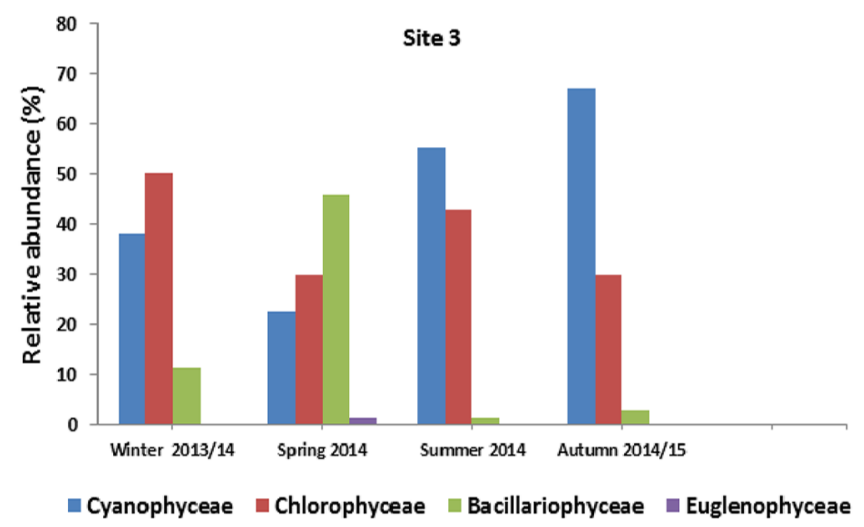

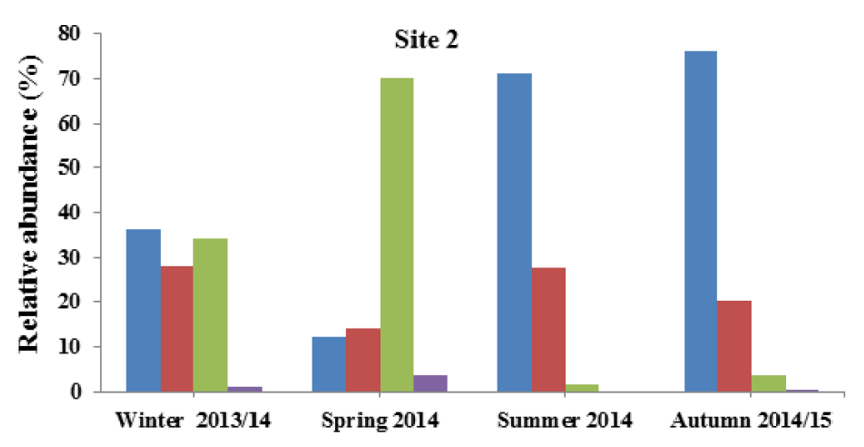

— Cyanophyceae $\backsim$ Chlorophyceae $\square$ Bacillariophyceae $\square$ Euglenophyceae

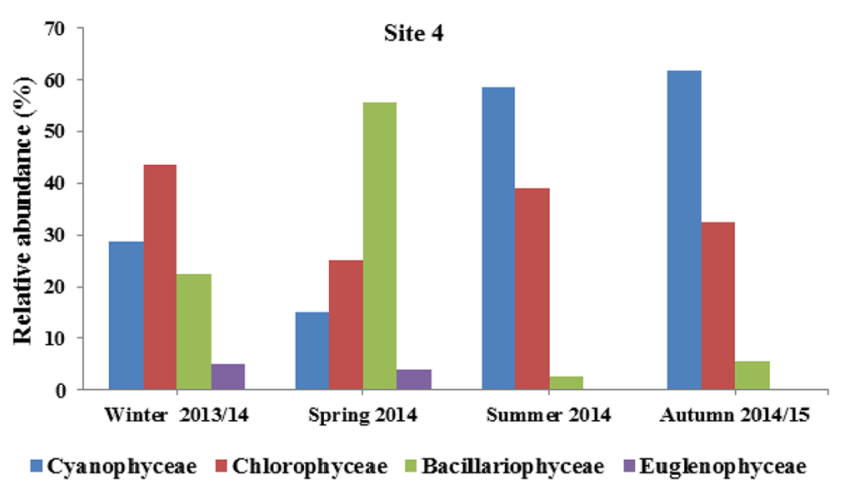

Fig. 2. Seasonal relative abundance of phytoplankton in Lake Chamo 2013-2014.

\subsection{Statistical analysis}

One-way ANOVA followed by Tukey's honest significant differences test was used to compare the spatial and temporal variation in phytoplankton diversity and physicochemical parameters, and partial correlation analysis was performed with SPSS (IBM@SPSS Statistics ver. 20, New York, USA). PAST programme, Hammer et al. (2001), was used to run Simpson's index, Shannon equitability index, species diversity (Shannon's index, $H^{\prime}$ ), Margalefs Species Diversity $(d)$ (Magurran, 2004) and evenness (Pileou's index, $J$ ) in evaluating phytoplankton community structure.

\section{Results}

\subsection{Physicochemical characteristics of Lake Chamo}

Water $\mathrm{pH}$ ranged from $8.87 \pm 0.25(\mathrm{Mean} \pm \mathrm{SD})$ in autumn (site 1) to $9.83 \pm 0.79$ in summer (site 3 . Significant differences in $\mathrm{pH}$ were observed across different seasons at site 1 (Tab. 1). Water temperature was highest $\left(30.4 \pm 0.21^{\circ} \mathrm{C}\right)$ in spring 2014 at site 3 and lowest $26.0 \pm 0.12^{\circ} \mathrm{C}$ during summer 2014 at site 2 . The mean value of transparency ranged from $12 \pm 0.78 \mathrm{~cm}$ during summer (site 1) to a $60 \pm 0.21 \mathrm{~cm}$ in spring 2014 (site 2), and significant differences were also observed across the different seasons and sampling sites. Dissolved oxygen concentrations decreased in summer and autumn, while increased in winter and spring. Transparency remained very low during the rainy season due to increased turbidity. The mean value of electrical conductivity ranged from
$1253 \pm 1.24 \mathrm{~ms} / \mathrm{cm}$ at site 1 in the summer to $2127 \pm 0.98 \mathrm{~ms} / \mathrm{cm}$ during spring at site 3 .

The mean value of TDS ranged from $595 \pm 5.10 \mathrm{mg} / \mathrm{L}$ at site 1 during summer to $924 \pm 3.65 \mathrm{mg} / \mathrm{L}$ at site 3 during spring (Tab. 1). There was significant variation in the value of TDS among the sampling sites and between the seasons $(p<0.05)$, site 1 having significantly higher value than site 1 and 3 . The mean value of TDS at summer season is significantly lower than all the other seasons. The mean value of salinity ranged from $0.6 \pm 0.01 \mathrm{ppt}$ at site 1 during summer to $0.93 \pm 0.08 \mathrm{ppt}$ at site 3 during spring season and there was not significant variation in the value of salinity among the sampling sites and seasons $(p<0.05)$.

\subsection{Phytoplankton species composition and abundance}

A total of 18 genera belonging to four different taxonomic groups were identified (Tab. 4). The three groups, Cyanophyta, Chlorophyta and Bacillariophyta accounted $96 \%$ of the total phytoplankton abundance (Fig. 2). Cyanophyta was the most abundant group representing $46.35 \%$ of the total abundance, whilst Chlorophyta (blue green algae) had the highest number of genera, and represented $34.06 \%$ of the total abundance. Bacillariophyta (Diatoms) represented $18.42 \%$ of the total abundance split between genera. Euglenophyta was the least represented group with only $1.17 \%$ of the total.

Phytoplankton species composition and abundance in Lake Chamo showed variation across different seasons and sampling sites during the study period (Fig. 3). During the 

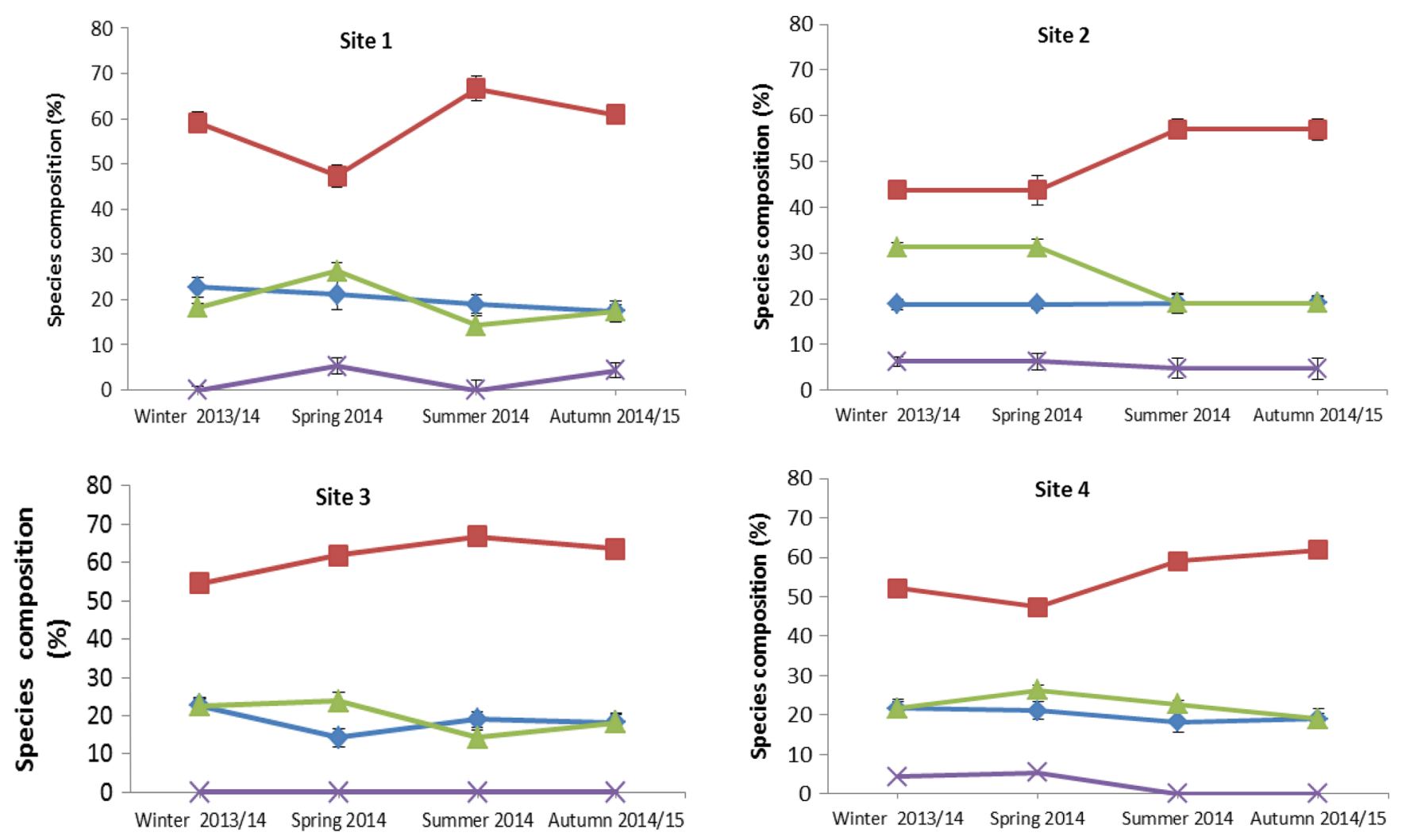

$\multimap$ Cyanophyceae $\rightarrow$ Chlorophyceae $\multimap$ Bacillariophyceae $\leadsto$ Euglenophyceae

Fig. 3. Seasonal phytoplankton composition in Lake Chamo 2013-2014.

dry and rainy season, Cyanophyta was the dominant group, followed by Bacillariophyta and Chlorophyta. Dense phytoplankton populations developed during winter and autumn seasons, immediately after the rainy season. Anabaena, Microcystis and Scendesmus species dominated the lake during autumn and winter seasons. Among the Bacillariophyta, Cyclotella and Amphora species were the most abundant during the pre and post rainy season in all sites. Of the Chlorophyta, Pediastrum, Scendesmus and Closterium species showed the highest abundance during the rainy seasons (July to September). Overall, the four seasons exhibit different phytoplankton species composition across different sites.

\subsection{Diversity indices of phytoplankton across different sampling sites of Lake Chamo}

The highest Shannon-Wiener's diversity index $\left(\mathrm{H}^{1}=2.58 \pm 0.14\right)$ was recorded at site 4 during winter 2013 / 14 season, while the lowest $\left(\mathrm{H}^{1}=1.79 \pm 0.08\right)$ was recorded at site 2 during autumn 2014 (Tab. 2). Margalefs Species Diversity $(d)$ was highest $(2.37 \pm 0.27)$ during autumn at site 1 and lowest at site $2(1.53 \pm 0.01)$ during winter $2013 / 14$. Highest and lowest Simpsons' index $(1 / D)$ of $10.44 \pm 0.06$ and $2.91 \pm 0.23$ were recorded at site 4 and site 2 , during winter and autumn respectively. Species Evenness was lowest $(0.58 \pm 0.04)$ at site 2 during autumn and highest $(0.83 \pm 0.06)$ was recorded at site 4 during spring season. The diversity was high during winter season in all sites.

\subsection{Correlation analysis of phytoplankton group with some environmental factors}

The results of the partial correlation analysis showed the average Cyanophyta count was positively and non-significantly $(p>0.05)$ correlated with the water temperature and turbidity of the lake (Tab. 3). However, total nitrogen positively and significantly correlated with Cyanophyta count. Positive and significant correlation was also observed between Chlorophyta count and the water temperature of the lake. A non- significant and negative correlation was found between water temperature and, Euglenophyta and Bacillariophyta counts. Total dissolved solids also showed non-significant and positive correlation with these counts.

\section{Discussion}

\subsection{Physicochemical and phytoplankton conditions}

Our current understanding of the seasonal and spatial variation of phytoplankton with environmental factors is insufficient in Lake Chamo. Seasonal variations in phytoplankton are related to a variety of environmental factors in aquatic environments (Cetin and Sen, 2004). Water temperature and transparency are among the most important physical factors affecting the distribution and seasonal variations of phytoplankton (Mosisch et al., 1999). During the study period Lake Chamo water temperature varied between $26.0 \pm 0.12^{\circ} \mathrm{C}$ to $30.4 \pm 0.21^{\circ} \mathrm{C}$. This value is a little higher to the reported 
Table 2. Diversity indices measurement of phytoplankton in Lake Chamo during winter 2013/14 (season I), spring 2014 (season II), summer 2014 (season III), and autumn 2014 (season IV).

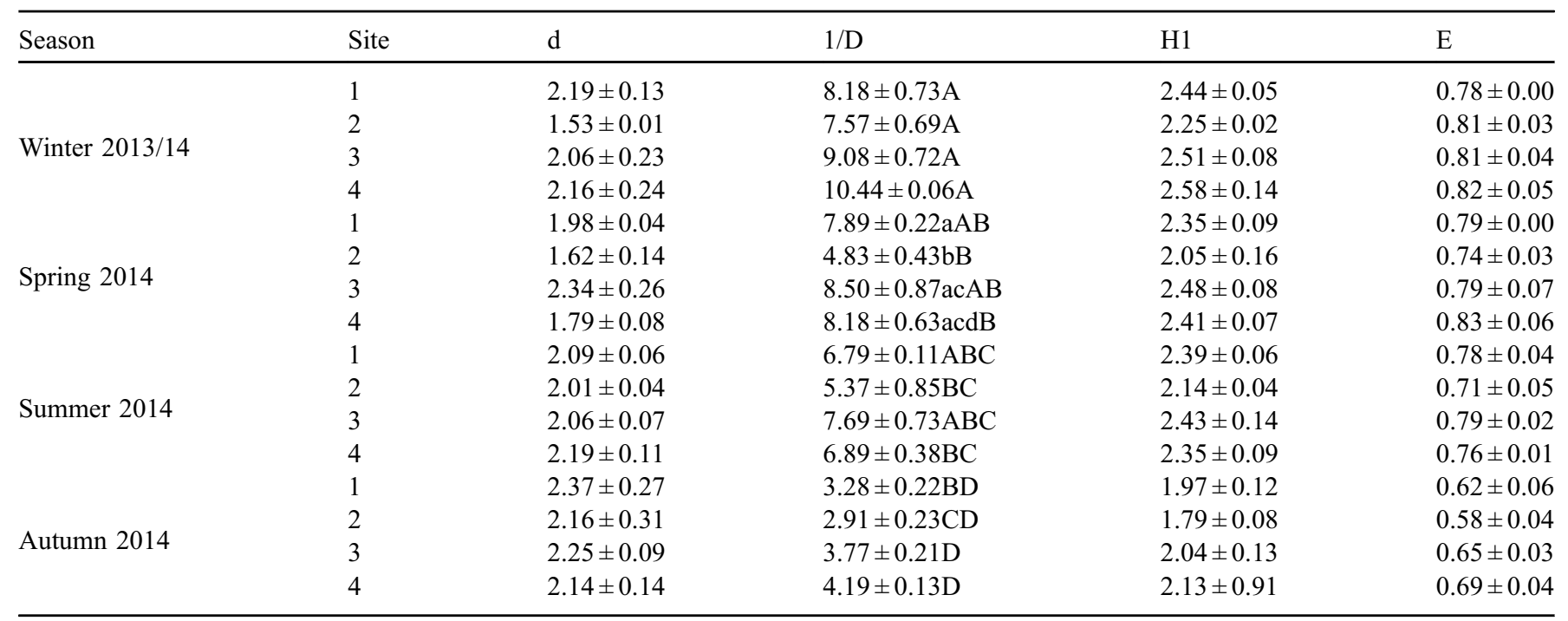

a,b,c,d Means within a column followed by the same superscripts are not significantly different among the sampling sites.

A, B, C, D Means within a column followed by the same superscripts are not significantly different among the sampling seasons.

Table 3. Correlation coefficients found by a partial correlation analysis of phytoplankton group (average count) and various environmental factors in Lake Chamo 2013-2014/15.

\begin{tabular}{lllll}
\hline & Cyanophyta & Chlorophyta & Euglenophyta & Bacillariophyta \\
\hline Temp. $\left({ }^{\circ} \mathrm{C}\right)$ & 0.89 & $0.94^{*}$ & -0.94 & -0.95 \\
DO & -0.51 & -0.07 & 0.40 & 0.36 \\
Transparency & -0.99 & -0.81 & 0.96 & 0.94 \\
TDS & -0.73 & -0.96 & 0.81 & 0.83 \\
Turbidity & 0.96 & 0.73 & -0.91 & -0.89 \\
Total nitrogen & $0.99^{*}$ & 0.83 & -0.97 & -0.96 \\
\hline
\end{tabular}

${ }^{*}$ Denotes $p<0.05$ (two-tailed).

values of other Ethiopian Rift Valley Lakes, such as Abijata and Langano $18-27^{\circ} \mathrm{C}$ (Kebede et al., 1994; Kumssa and Bekele, 2013); Lakes Ziway 18.5-27.5 ${ }^{\circ} \mathrm{C}$ (Girma, 1988); and Hawassa $20.98-21.33^{\circ} \mathrm{C}$ (Abate et al., 2015). The change in water temperature of Lake Chamo affects the phytoplankton diversity and abundance. This result was in agreement with the reports of Richardson et al. (2000) and Lund (1965), in fresh water ecosystem water temperature strongly regulates seasonal variations of phytoplankton. The increase in phytoplankton diversity and abundance during winter and spring seasons in Lake Chamo could also be a result of the increasing water temperature. Similar reports also showed that water temperature of Lake Chamo varied among seasons (Tafa and Assefa, 2014). According to their findings, the water temperature of Lake Chamo increased in January due to the increase in air temperature. Except for site 1 (mouth of Kulfo river), the $\mathrm{pH}$ values were not significantly different in all seasons. The $\mathrm{pH}$ values recorded in this study were comparable with the results obtained by other researchers, (8.53-9.44) in the same lake (Eyasu, 2004; Tafa and Assefa, 2014; Lemma and Desta,
2016). The $\mathrm{pH}$ values were relatively low during the rainy seasons, which may be attributed to the decomposition of organic matter (Tafa and Assefa, 2014). However, the $\mathrm{pH}$ values increased after the rainy season. This relatively increases the photosynthetic activities of phytoplankton.

The TDS values of Lake Chamo $(924 \pm 3.651$ to $595 \pm 5.10 \mathrm{mg} / \mathrm{L})$ were higher than Lake Hawassa $455.6 \mathrm{mg} / \mathrm{L}$ (Abate et al., 2015). But this value is far less than the nearby rift valley lake, Lake Abaya reported a value of $1,522.45 \mathrm{mg} / \mathrm{L}$ (Huib and Herco, 2006). This was mainly attributed to the high rate of evaporation and consequent reduction in the water level during spring.

Salinity of Lake Chamo considered to be one of the main factor responsible for the deterioration of the environmental conditions of Lake Chamo and the drop in its phytoplankton and fish diversity (Tafa and Assefa, 2014; Lemma and Desta, 2016). The minimum salinity recorded was $0.6 \pm 0.01 \mathrm{ppt}$ at site 1 during summer and the maximum was $0.93 \pm 0.08 \mathrm{ppt}$ at site 3 during spring season. The highest salinity during spring season was attributed to the high rate of evaporation in the 
region, while the lowest may be due to the effect of dilution arises from drainage water from Kulfo, Sile and other rivers during the rainy summer season (Tafa and Assefa, 2014).

Phytoplankton species composition in this study showed a decline at the onset of the rainy season (summer) which corresponded to increased dilution and water turbidity. This result is comparable to the study conducted on Lake Tana (Wondie et al., 2007), who reported that phytoplankton biomass declined during the rainy season as a result of increased turbidity. According to this study the phytoplankton community of Lake Chamo consisted of mainly of Cyanophyta, Chlorophyta, Bacillariophyta and Euglenophyta groups. In line with this, (Golubtsov and Habteselassie, 2010), reported Cyanophyta, Chlorophyta and Bacillariophyta being the main phytoplankton groups in Lake Chamo. The seasonal diversity and abundance of phytoplankton in Lake Chamo is mainly related with the range of physicochemical parameters such as temperature, salinity, alkalinity, nitrate-nitrogen and phosphate. The observed variation in plankton species dominance during the study may be attributed to variations in the optimal conditions for the various species (Jiang et al., 2014; Lemma and Desta, 2016). The variations in phytoplankton cell count across different season have also been reported in other Ethiopian rift valley lakes. For example, Kumssa and Bekele (2013) showed that there were marked variations in phytoplankton population in the Abijata Shala Ethiopian rift valley lake, apparently due to differences in water quality. The finding of this study also showed that Lake Chamo was dominated by Cyanophyta with noticeable changes between seasons. The phytoplankton population changes were characterized by dominance shifts between Cyanophyta and Chlorophyta. The most abundant Cyanophyta was Anabaena sp during autumn and winter, while the dominant Chlorophyta during these seasons were Scendesmus, Cosmarium and Pediastrum species. Of the Bacillariophyta Cyclotella and Amphora species were the most abundant during the dry winter season. Moreover, the highest Shannon-Wiener's diversity index was recorded during the dry winter season, while the lowest was recorded during autumn. This finding agrees with (Jiang et al., 2014), who reported Lake Chaohu was inhabited by different phytoplankton species and dominated by Microcystis viridis, Microcystis flos-aquae, and Anabaena circinalis. These results are also in agreement with Kumssa and Bekele (2013) and Tewodros and Afework (2014), who reported that Bacillariophyta were more dominant during the dry season, especially Cyclotella and Navicula species dominated Abijata- Shalla Lakes (Tab. 2).

\section{Conclusion}

In this study, a total of 18 genera belonging to four different taxonomic groups were identified, among which Cyanophyta, Chlorophyta and Bacillariophyta accounted $96 \%$ of the total phytoplankton abundance. Cyanophyta was the most abundant group representing $46.35 \%$ of the total abundance, whilst Chlorophyta had the highest number of genera, and represented $34.06 \%$ of the total abundance. Euglenophyta was the least abundant group in the study period. The four seasons exhibit different phytoplankton species composition across different sites, but the overall species diversity was high during winter season in all sampling sites. Moreover, positive and significant correlation was observed between Chlorophyta count and water temperature of the lake. The mean Cyanophyta count was also positively and non-significantly correlated with water temperature and turbidity of the lake. A non- significant and negative correlation was found between water temperature and, Euglenophyta and Bacillariophyta counts.

\section{References}

Abate B, Woldesenbet A, Fitamo D. 2015. Water quality assessment of lake hawassa for multiple designated water uses. Water Util J 9: 47-60.

APHA. 2005. Standard methods nonalcoholic beverages, 18th ed, American Water Works Association and Water Pollution Control Federation, New York.

Archibald REM. 1972. Diversity in some South African diatom associations and its relation to water quality. Water Res 6: 1229-1238, doi:10.1016/0043-1354(72)90023-1.

Ariyadej C, Tansakul R, Tansakul P, Angsupanich S. 2004. Phytoplankton diversity and its relationships to the physicochemical environment in the Banglang reservoir, Yala Province. Songklanakarin J Sci Technol 26: 596-607.

Cetin AK, Sen B. 2004. Seasonal distribution of Phytoplankton in Orduzu dam lake. Turk $J$ Bot 28: 279-285.

Desikachary TV. 1959. Cyanophyta. New Delhi, India: ICAR.

Eyasu S. The temporal and spatial variations in the biomass and photosynthetic production of Phytoplankton in relation to some physico- chemical variables in lake Chamo, Addis Ababa University, Addis Ababa, 2004.

Girma T. A seasonal study on primary production in relation to light and nutrients in lake Ziway, Addis Ababa University, Ethiopia, 1988.

Golubtsov AS, Habteselassie R. 2010. Fish faunas of the Chamo-Abaya and Chew Bahir Basins in Southern portion of the Ethiopian Rift Valley: origin and prospects for survival. Aquat Ecosyst Health Manag 13: 47-55, doi:10.1080/14634980903578506.

Hailemicael A, Raju AJS. 2010. Challenges and opportunities of Chamo Lake-Wetland biodiversity, Ethiopia 22: 223-233.

Huib H, Herco J. Ecosystems for water, food and economic development in the Ethiopian Central Rift Valley (BO-10-00622), Wageningen, The Netherlands, 2006.

Jagadeeshappa KC, Kumara V. 2013. Influence of physico-chemical parameters on the diversity of Plankton species in Wetlands of Tiptur Taluk, Tumkur Dist, Karnataka State, India. Carib J Sci Tech 1: 185-193. http://caribjscitech.com/.

Jenkerson CG, Hickman M. 2007. Interrelationship among the Epipelon, Epiphyton and Phytoplankton in a Entrophic Lake. Int Reve Dev Gesamten Hydrobiol Hychrograp 71: 557-579.

Jiang YJ, He W, Liu WX, Qin N, Ouyang HL, Wang QM, Kong XZ et al., 2014. The seasonal and spatial variations of phytoplankton community and their correlation with environmental factors in a large Eutrophic Chinese Lake (Lake Chaohu). Ecol Indic 40: 5867, doi:10.1016/j.ecolind.2014.01.006.

Kebede E, Mariam ZG, Ahlgren I. 1994. The Ethiopian Rift Valley Lakes: chemical characteristics of a salinity-alkalinity series. Hydrobiologia 288: 1-12, doi:10.1007/BF00006801.

Kumssa T, Bekele A. 2013. Phytoplankton composition and parameters study in water bodies of Abijata - Shalla Lakes National Park (ASLNP), Ethiopia. Greener J Biol Sci 4: 68-76. 
Lemma B, Desta H. 2016. Review of the natural conditions and anthropogenic threats to the Ethiopian rift valley rivers and lakes. Lakes Reserv: Res Manag 21: 133-51, doi:10.1111/lre.12126.

Lund JWG. 1965. The ecology of the freshwater Phytoplankton. Biol Rev 40: 231-293.

Magurran AE. Ecological diversity and its measurement, Princeton university press, New Jersey, 2004.

Mosisch TD, Bunn SE, Davies PM, Marshall CJ. 1999. Effects of shade and nutrient manipulation on Periphyton growth in a Subtropical stream. Aquat Bot 64: 167-177, doi:10.1016/ S0304-3770(99)00014-5.

Nasser KMM, Sureshkumar S. 2014. Seasonal variation and biodiversity of Phytoplankton in Parambikulam Reservoir, Western Ghats, Kerala. Int Jpure Appl Biosci 2: 272-280.

Philipose MT. 1962. Chlorococcales, ICAR, New Delhi.

Prescott GW. 1982. Algae of the western great lakes area, Otto Kaetz Science publishers, W. German.

Richardson TL, Gibson CE, Heaney SI. 2000. Temperature, growth and seasonal succession of Phytoplankton in Lake Baikal, Siberia. Freshw Biol 44: 431-440, doi:10.1046/j.1365-2427.2000.00581.x.

Rothhaupt KO. 2000. Plankton population dynamics: food web interactions and biotic constraints. Freshw Biol 45: 105-109.

Sarode PT, Kamath ND. Fresh water Diatoms of Maharastra, Saikrupa Prakashan, Aurangabad, 1984.

Shashi S, Kiran B, Puttaiah E, Shivaraj Y, Mahadevan M. 2008. Phytoplankton as index of water quality with reference to industrial pollution. J Environ Biol 29: 233-236.

Siddaraju, Deviprasad AG. 2012. Distribution and diversity of Phytoplankton in two lakes of Mandya. Natl Mon Refereed
JResSciTechnol 1: 23. http://www.abhinavjournal.com/images/ Science \& Technology/Jun12/2.pdf.

Sorokin DY, Berben T, Melton ED, Overmars L, Vavourakis CD, Muyzer G. 2014. Microbial diversity and biogeochemical cycling in Soda lakes. Extremophiles 18: 791-809, doi:10.1007/ s00792-014-0670-9.

Tafa B, Assefa E. 2014. Detection of Copper and Zinc (Heavy Metals) in water of Lake Chamo, Arbaminch Ethiopia. World J Chemical Educ 2: 42-47, doi:10.12691/WJCE-2-3-3.

WarwickRM. 1992. Ecological diversity and its measurement, in: Anne E. Magurran (Ed.), Chapman and Hall, London, Second Edition (Paperback), 1991, pp. 179, GBP 13.95; ISBN 0-412-38330-6 (Paperback), Journal of experimental marine biology and ecology 159 (2), Elsevier: 279-80, doi:10.1016/0022-0981(92)90042-9.

Washington HG. 1984. Diversity, biotic and similarity indices: a review with special relevance to aquatic ecosystems. Water Res 18: 653-694.

Welch PS. Limnological methods, Revista Europea de Estudios Latinoamericanos Y Del Caribe, Mc hill Book Company, New York, 1948.

Willén E, Ahlgren G, Tilahun G. 2011. Cyanotoxin production in seven Ethiopian Rift Valley lakes. Inland Waters 1 (Steyn 1945): 81-91, doi:10.5268/IW-1.2.391.

Wondie A, Seyoum A, Ae M, Vijverberg J, Dejen E. 2007. Seasonal variation in primary production of a large high altitude Tropical lake (lake Tana, Ethiopia): effects of nutrient availability and water transparency. Aquat Ecol 41: 195-207, doi:10.1007/ s10452-007-9080-8.

Xu F-L, Jørgensen SE, Tao S. 1999. Ecological indicators for assessing freshwater ecosystem health. Ecol Model 116: 77-106.

Cite this article as: Fekadu A, Chanie S. 2017. A seasonal study on phytoplankton diversity and dynamics of Lake Chamo, Ethiopia. Aquat. Living Resour. 30: 40 


\section{Appendix}

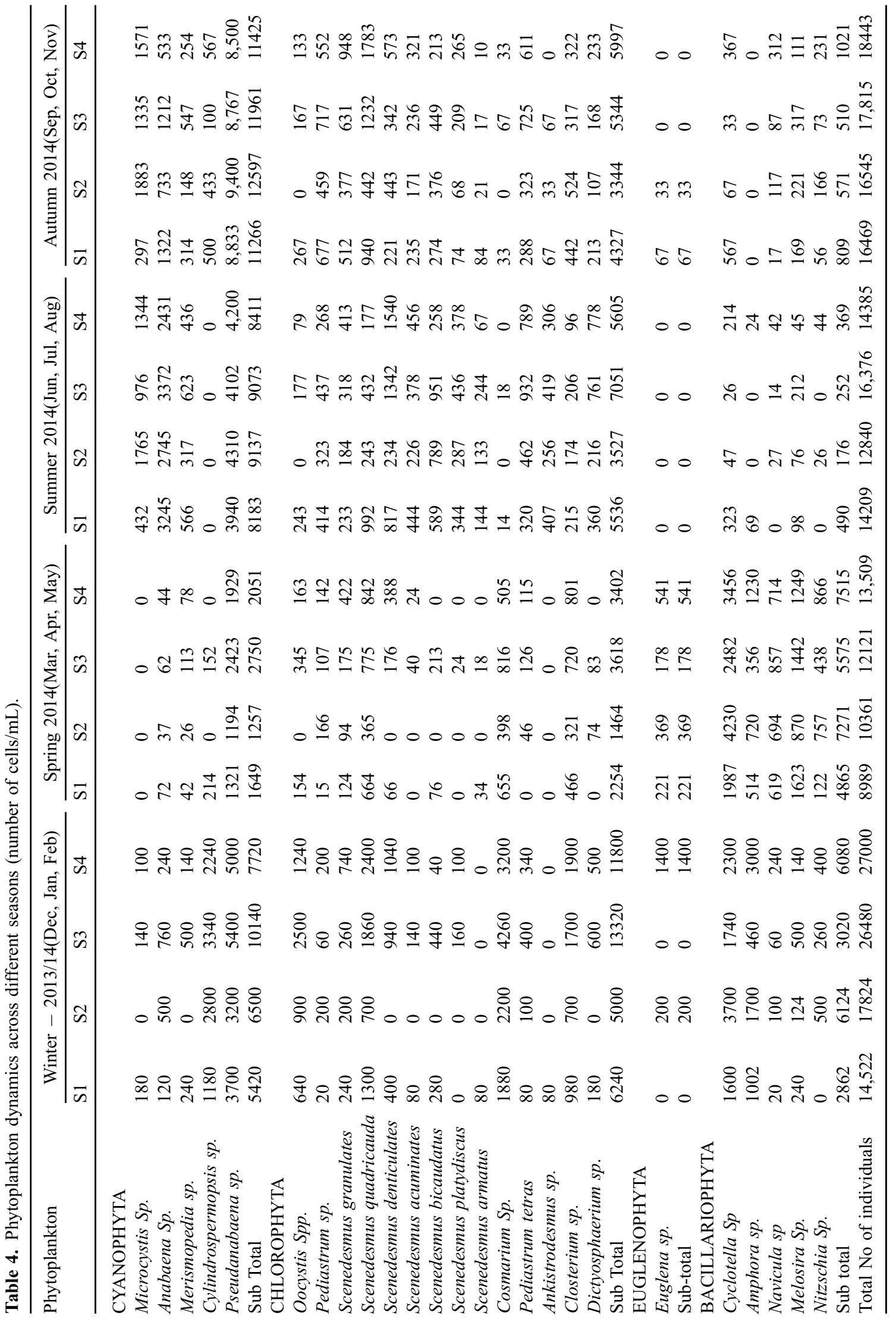

